\title{
Narratives from the Margins of the State: Resisting the Politics of Exceptionality in Comuna 13
}

Gustavo Rojas-PÁEZ*

Rojas-Páez, G., 2018. Narratives from the Margins of the State: Resisting the Politics of Exceptionality in Comuna 13. Oñati Socio-legal Series [online], 8 (6), 901-924. Received : 16-01-2018; Accepted: 01-10-2018. Available from: https://doi.org/10.35295/osls.iisl/0000-0000-0000-0972

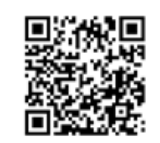

\begin{abstract}
This article questions the implementation of the "state of exception" in marginal urban areas of Colombia. In so doing, it takes as a case study the military operations carried out in 2002, in Comuna 13, an urban district of Medellín. More than a decade after these military operations, communities whose lives were significantly affected by the operations have denounced the commission of an important number of human rights violations in the Comuna. These human rights violations, which include interurban displacements and Enforced Disappearances (ED) occurred after the so-called securitisation of the neighbourhood and challenge the notion of security that underpins "state of exception" policies. The overall aim of the article is to highlight the importance of the narratives of resistance that contest the implementation of state of exception policies. These narratives urge us to think beyond the "friend or foe" logic that has justified military interventions of past decades in urban areas of the Global South.
\end{abstract}

\section{Key words}

State of exception; enforced disappearances; transitional justice; narratives of resistance

\section{Resumen}

Este artículo cuestiona la implementación del "estado de excepción" en las zonas marginales de las ciudades colombianas. Para tal propósito, se analiza la militarización de la Comuna 13 en el 2002. El estudio de caso ilustra cómo después de una década de la militarización del distrito urbano, las comunidades sobrevivientes han denunciado violaciones de derechos humanos ocurridas después de la llamada "securitización" de la Comuna en el 2002. Las violaciones incluyen desplazamiento intraurbano y varios casos de desaparición forzada. Esta situación supone una crítica

The author would like to thank the José Manuel Atiles Osoria and David Whyte for their encouragement to publish this article. A draft of the article was presented at the workshop State of exception, Law and the Economy, which took place at the IISL in 2016. The article is part of a broader project entitled Global constitutionalism, Multiculturalism and Transitional Justice, which I conduct at the socio-legal research centre of Universidad Libre, Colombia.

* Gustavo Rojas-Páez is Lecturer in Legal Theory. Socio-legal research centre, Universidad Libre, School of Law. Research Associate Sussex Rights and J ustice Research Centre. Postal Address: Universidad Libre, School of Law, Cll 8 5-80, Campus La Candelaria, Bogota D.C., Colombia. Email address: grojaspaez@yahoo.es ORCID: https://orcid.org/0000-0001-6317-0486

\section{(c)) EY-NC-ND}

Oñati International Institute for the Sociology of Law Antigua Universidad s/n - Apdo.28 20560 Oñati - Gipuzkoa - Spain

Tel. (+34) 943783064 
a la idea de seguridad que fundamenta la política del estado de excepción. El objetivo es destacar la importancia de las narrativas de resistencia que confrontan la implementación del estado de excepción. Estas narrativas nos exhortan a pensar más allá de la lógica "amigo-enemigo" la cual ha justificado intervenciones militares en zonas urbanas del sur global en las últimas décadas.

\section{Palabras claves}

Estado de Excepción; desaparición forzada; justicia transicional; narrativas de resistencia 


\section{Table of contents / Índice}

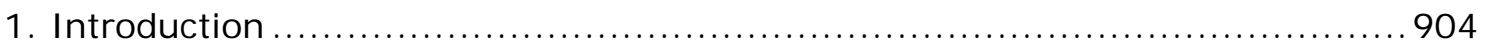

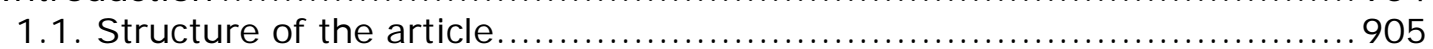

1.2. Methodology: The narrative approach ..................................... 905

1.3. Theoretical remarks.................................................. 906

Section I. The district's genesis and expansion, laws of exception

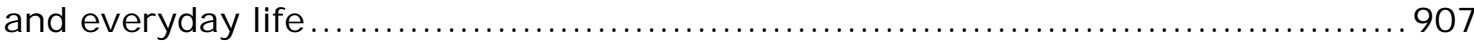

2.1. Configuration of the first neighbourhoods ............................... 908

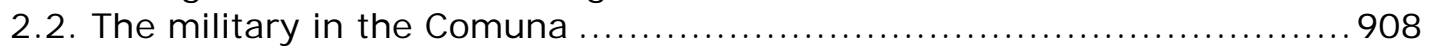

2.3. Territorial control in Comuna 13:

the competing interests of armed groups..................................... 909

2.4. M19 camps, Medellín Cartel and the paramilitaries ....................... 909

2.5. War on drugs and counter-insurgency discourses ........................ 910

2.6. A Ciriri's archive........................................................ 911

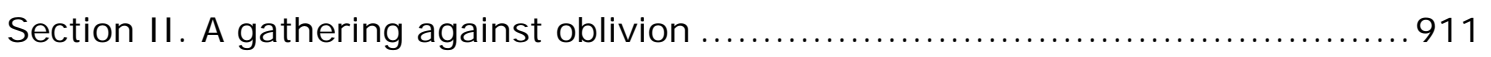

3.1. "Come out with your little white flags

and we will open fire on all of you" ........................................... 912

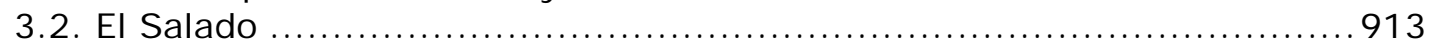

3.3. Legal interpretations and the continuum of violence ..................... 913

3.4. Five female leaders against the laws of exception $\ldots \ldots \ldots \ldots \ldots \ldots \ldots \ldots \ldots \ldots 15$

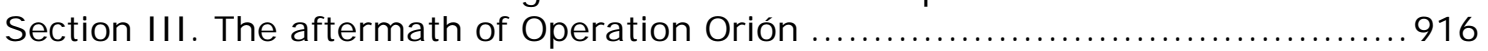

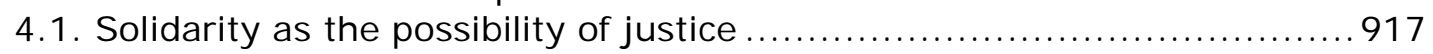

4.2. Unearthing the truth behind the rates .................................. 918

4.3. Transitional Justice as an expression of exceptionality .................... 918

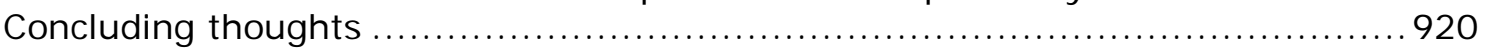

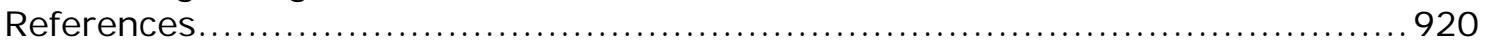

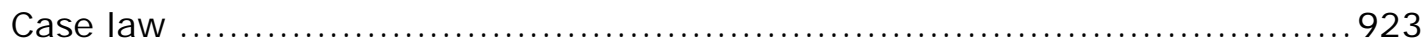

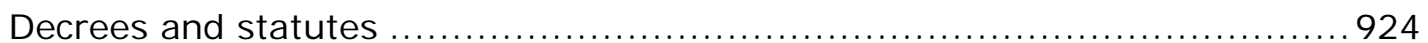

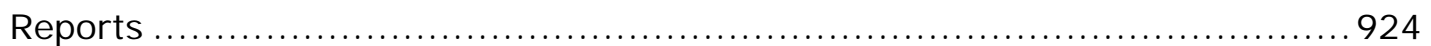




\section{I ntroduction}

On November 2016 the Inter-American Court of Human Rights declared that the Colombian state had failed to prevent the assassination of community leader Ana Teresa Yarce (Yarce y otras v Colombia, 2016). Ana Teresa was a well-known, human rights defender in Comuna $13^{1}$ who was assassinated, in 2004 , by paramilitaries operating in her neighbourhood. The ICHR's ruling also declared that the Colombian state had failed to provide adequate security measures to other female leaders who had to flee due to death threats related to their activities in the community (Yarce $v$ Colombia).

One of the important aspects of the ICHR's ruling is that it shows the persistence of violence after the implementation of the laws of exception used to justify the various military interventions of 2002. The operations occurred during a period described by academics as the "Urbanisation of Colombia's war" (Centro Nacional de Memoria Histórica - hereafter, CNMH- 2011). ${ }^{2}$ According to the government of the time, in the name of security, the use of military force was necessary to combat enemies of the state who were now located in the slums of Colombia's large cities. It was the beginning of the century and although the end of the Cold War had given rise to processes of democratisation in Latin America, this was not the case in Colombia. In fact, the country became one of the largest recipients of US military aid in the world (Stokes 2003). Subsequently, the right-wing governments of the first decade of the century in Colombia adopted securitisation policies, through which elements of the counterinsurgency rhetoric of the Cold War merged with discourses on the War on Drugs and the War on Terror (Ramírez 2010). This combination of discourses was presented as criminal policy of exception called Democratic Security Policy (hereafter, DSP). The obsession with security went hand in hand with the continued implementation of the neoliberal economic model that benefitted foreign investment and business elites whose interests were guaranteed through security, understood as the militarisation of everyday life.

This background sets the context for this article, in which I will reflect upon the ways in which communities inhabiting areas affected by securitisation policies resist and advance demands for justice that are relevant to understanding the continuum of violence (Bourgois 2009) caused by laws of exception in multi-actor armed conflicts like the one endured by Colombia. My contention is that observing the narratives of resistance of stigmatised communities within contexts of exceptionality is fundamental to understanding not only the violence of states of exception, but also the formation of subjectivities that contest it through demands for justice, truth and memory

The case study of Comuna 13 exemplifies the continuum of violence that marginalised communities in Colombia face. Contrary to the official narrative of the time that maintained that security improved in Medellín with a significant decrease in homicide rates after the military interventions of 2002, heinous crimes such as Enforced Disappearances (ED) and inter-urban displacement continued to occur. The experiences of the individuals living this violence created by the exceptionality directly contradict the official narrative. ${ }^{3}$

\footnotetext{
1 The city of Medellín is divided into 16 Communes, some of which are known by their name (e.g. El Poblado) and others by their number. Although they may be compared to boroughs in some British or US cities, they have no control over budgets, though they may exercise certain functions through the Local Administrative Boards for the management of the city. Here I have opted to use the Spanish name "Comuna 13" as it is the commonly used name for the area.

2 This urbanisation of Colombia's war is partly a myth. The reality is that for much of the 1980s and 1990s the war had already been urbanised in major cities such as Medellín, Buenaventura, Barrancabermeja, Cúcuta and also to some extent in the south of Bogotá.

3 According to recent reports by the National Centre of Historical Memory, during the lasts four decades, nearly 83.000 persons were victims of Enforced Disappearance in Colombia; see CNMH 2016.
} 


\subsection{Structure of the article}

The article is structured as follows. The remainder of this introduction discusses the theory and methodology of the article. The first section deals with the historical configuration of urban violence, both in Medellín and in the Comuna 13. It provides a description of the spatial dynamics, the social and political meanings surrounding urban life in Comuna 13, and the politics of exceptionality. The second section sheds light on the phenomenon of inter-urban displacement in Comuna 13, focusing on the mass displacement of the urban population that occurred in El Salado, one of the neighbourhoods of Comuna 13, on J une $29^{\text {th }} 2002$. The third section draws attention to the grassroots international commission that sought/demanded clarification of the human rights violations that occurred during and after the military interventions of 2002. This section reflects upon the efforts of the community to find the remains of people who were executed by paramilitaries who had taken control of the area after the military interventions. The bodies of the victims of these crimes were thrown into a public waste dump located in Comuna 13, known as La Escombrera ${ }^{4}$ which is considered by many to be one of the largest mass graves in Colombia.

\subsection{Methodology: The narrative approach}

This article adopts a narrative approach (Jackson 2002), and centres specifically on narratives of resistance to exceptionality laws that have been endured by Comuna 13 's inhabitants. The narrative approach is an important instrument to understanding the agency of marginalised communities that exemplify the margins of the state in Das and Poole's terms (Das and Poole 2004). The implementation of the state of exception has a major impact in marginalised places and populations located at the margins of the state (Das and Poole 2004). This does not mean that in these sites the state is absent or weak; on the contrary, in creating marginalised areas and attempting to control them through force, the state is also present (Civico 2012).

The analysis of narratives has been used recently by Robinson in his work about the Troubles in Ireland. Robinson shows how the state of exception was used in that particular period of the Northern Irish conflict (1968-1998). The importance of Robinson's work resides upon his interpretation of Agamben's notion of State of Exemption. For Robinson,

[t]he state of exception is an institutionalised fiction with the power of performative reality that facilitates the suspension of the citizenship and humanity of a political subject in response to a constructed state of political crises. (Robinson 2018,67)

Following Robinson, this article is concerned with the performativity of the state of exception as a means to create discursive narratives about war and its legal and political representations, by the state and through law. These representations are juxtaposed against the narratives of the people who were the "victims" of the state of exception.

The narrative approach is very important to the purpose of this article because it allows us to: a) show the distrust of survivors of the military operations that marked the beginning of the DSP in Colombia and b) observe a different interpretation of the securitization policies that took place in the Comuna, one that imbues meaning to the suffering of victims of two crimes that mark the continuum of violence in contemporary Colombia: Enforced Disappearance and Displacement.

In sum, the narrative approach is fundamental to illustrating the opposing views towards exceptionality laws implemented by the DSP, and allows us to show a counter-narrative to the official discourse on securitization, which after the military operations of the beginning of the century, upheld that the Comuna became a safer place in Medellin. Therefore, whereas for advocates of DSP, the bodies thrown into

\footnotetext{
${ }^{4}$ La Escombrera simply means rubbish dump, though here it is also a proper noun i.e. the name of the particular dump.
} 
the Escombrera are meaningless, for survivors and victims of exceptionality laws, the bodies in the dump site have an important significance, which can only be grasped by observing survivors and victims' justice claims.

Through incorporating the narrative approach into my analysis I seek to shed light on the tension between legal truth and historical truth which has arisen within Colombia's Transitional Justice Scenario (Castillejo-Cuéllar 2013). The Comuna 13 experience shows an important link between securitization policies and the Transitional Justice discourse that began in Colombia in 2003 with the Santa Fe del Ralito accord signed by the first government of Álvaro Uribe and the United Self Defence groups (AUC), Colombia's largest right-wing paramilitary organisation.

\subsection{Theoretical remarks}

The implementation of laws of exception shows how the Colombian state has historically exercised its legislative powers. Following in the liberal tradition, the Colombian state has used law with political intentions in a 60-year, multi-actor armed conflict. This use of law is important to analyse what Norrie terms the "coordinative" character of criminal law (Norrie 2017, 28). The coordinative character of law refers to the "way in which law forces and canalises action through power" (Norrie 2017, 28). In Colombia the authoritarian nature of criminal law is expressed through state necessity, as exemplified by securitization policies in the beginning of this century.

In drawing on A Norrie's work, this article seeks to inquire about the moral groundings of the criminal law of exception, which permitted the military interventions in Comuna 13. In this vein the article shows how state law has a violent component that becomes normalized through its exceptionality narratives while also being contested by the communities affected by it.

Since exceptionality laws promote a moral narrative that leads to social indifference, the article highlights the fact that in the Comuna 13, communities have to coexist with a variety of actors including right-wing paramilitary groups, state police, state military, cartels, gangs, and leftist guerrilla groups that impose sanctions according to their interests. It is a situation of multilayered sovereignties (Uribe de Hincapié 1998), through which the law, including the law of the state, is, as Benjamin put it, nothing more than violence: "Law-making is power-making, assumption of power, and to that extent an immediate manifestation of violence" (Benjamin 1978/2007, 248).

This relationship between law and violence raises questions about the capacity of the law to bring about security and peace. In this vein, Norrie's recent insights on the ethics of justice play an important part in my analysis (Norrie 2017).

The article pits state narratives based on the state of exception (DSP and Peace and Justice Law) against the narratives of the communities that have been affected by declarations of state of exception. This shows the dialectical relationship between the judicial truth and the historical truth (Castillejo-Cuéllar 2013). In addressing this dialectical relationship, it is of particular interest to me to show how the narratives of a historically marginalised community contest the legal fiction of the state of exception by counter-posing demands for justice around crimes such as Enforced Disappearance and displacement that illustrate the structural harm caused by many years of war.

The article deals with a scenario of overlapping power structures on the margins of the state, which prompts us to think about the moral groundings of exceptionality and the "friend or foe" logic that has shaped criminal policy in Colombia. The context of these overlapping laws and power structures suggest that the idea of law as a set of norms that should be obeyed by citizens falls short in understanding the sociolegal reality of what Das and Poole call the margins of the state. On the contrary, an understanding of law as a "social fact" - as suggested by the social sciences - may prove useful in approaching the socio-legal realities of communities inhabiting the 
so-called lawless zones (Lemaitre 2015). At stake is the possibility of finding common ground on justice beyond its legalistic form (Norrie 2008).

The article is rooted in the empirical study of law. It combines recent insights of the anthropology of law in transitional justice scenarios (Castillejo-Cuéllar 2013) the anthropology of the state (Das and Poole 2004) and critical legal theory (Norrie 2017). In regard to critical law theory, the article is concerned with Norrie's insights on the moral grounds of punishment, the authoritarian character of criminal law, and the ethical dimension of law and its possibilities for human emancipation (Norrie 2017).

After having described the methodological and theoretical frameworks, in what follows, I will present the first section of the article which deals with the historical configuration of urban violence, both in Medellín and in Comuna 13. As will be shown urban violence has an important impact on the state discourses on exceptionality and on the narratives of inhabitants of Comuna 13.

\section{Section I. The district's genesis and expansion, laws of exception and everyday life}

Comuna 13 is a peripheral urban district of Medellín that comprises 19 neighbourhoods. Both the spatial and social configurations of Comuna 13 have been influenced by the multiple forms of violence deployed by different actors at different moments in Colombia's recent history (Blair et al. 2005, cited in INER et al. 2008). Forced displacement has deeply affected the district's social dynamics, given that many of the settlers of the Comuna 13 were peasants who had fled their towns following the bipartisan violence of the 1950s (CNMH 2011).

In his book Comuna 13 de Orión a La Escombrera (Aricapa 2015), the freelance journalist Ricardo Aricapa documented the testimonies of many settlers in the district. These testimonies describe the resilience of the inhabitants of Comuna 13 and the hardship of forced displacement in Colombia. For instance, Aricapa shows how the displaced population arrived in the city and settled in a place called Moravia between the 1950s and the late 1970s. In 1974 Moravia was turned into Medellín's rubbish dump, despite having a population of more than 15,000 people. Although many settlers remained and fought against evictions, many others moved to San Javier, one of the neighbourhoods of Comuna 13 (Aricapa 2015).

It is important to note that while the displaced population were forcibly migrating to large cities, laws passed under states of exception became permanent between 1950 and 1997 (Iturralde 2010). Between 1949 and 1991 Colombia lived under more than 30 years of states of exception, 17 of those occurring between 1970 and 1991 (García Villegas 2008). At the same time, a process of systemic land dispossession accentuated the asymmetric land tenure of the country. In the period known as La Violencia (1946-1958) around 2 million people were forcibly displaced, mostly from rural areas into cities (Oquist 1978). Displacement in Colombia must be seen as not only

a means of attacking the opposing ideological group, but also an end in itself (...) displacement is not just a byproduct of conflict, but at times it becomes the very object of conflict itself - facilitating land distribution from peasants and smallholders to larger landowners and corporations. (Olarte and Wall 2012, 323)

The fact that exceptionality laws were permanent (1949-1991) during the time in which Comuna 13 came into life shows a restricted understanding of citizenship that falls within Norrie's analysis of the authoritarian aspects of modern criminal law. Drawing on Newman's work and the forms of citizenship described by T.H Marshall, Norrie asserts that

responsibility and justice in the model of political citizenship rests upon individual rather than social premises, it is up to individuals to act responsibly within the law 
and, where they do not do so, they may be appropriately punished. (Norrie 2017, 39)

In this vein, the criminal law of exception implemented after the bipartisan violent period (La Violencia) showed that Colombia did not value the historical experience of the communities that settled in Comuna 13. This has translated into social indifference, as displacement and dispossession have not fully been taken into account by urban developers and other policy makers in Medellín.

\subsection{Configuration of the first neighbourhoods}

Comuna 13 is also an area that has suffered from land invasions on the periphery of Medellín. Apart from El Salado, which is the oldest neighbourhood of the district, founded towards the end of the $19^{\text {th }}$ century, many other neighbourhoods are the result of "invasions" or informal processes of urban settlement. In fact, neighbourhoods such as Independencias I, II and III arose from invasions of the hills surrounding the Comuna 13 and at some point were considered the largest urban invasions of the past century, even more so than the invasions that shaped the slums of Mexico City and Rio de Janeiro (Aricapa 2015). ${ }^{5}$

Although the settlements that brought Comuna 13 to life embody a history that illustrates the trajectories of displacement and dispossession of Colombia's lowintensity war, neither urban developers nor the country's lawmakers take this into account when dealing with urban security. As Julieta Lemaitre argues, given the restricted way in which we think about places affected by social exclusion, we tend to think that urban spaces such as the Comuna 13 are places that should be radically changed (Lemaitre 2015). They are considered terra nullius (Lemaitre 2015) or lawless places where the state should intervene, be it for the sake of development, environmental safety or security (see Atiles-Osoria 2018, in this volume).

\subsection{The military in the Comuna}

It was in the name of security that the state of exception was implemented in the urban district. In 2002, 12 military operations took place in Comuna 13 (CNMH 2011), the most brutal of which was Operation Orión, with more than 1,000 members of the police and the Colombian military entering the economically depressed district (Civico 2012). This military operation kick-started the implementation of the Democratic Security Policy (DSP) in Colombia, which was a continuation of the politics of exception that have characterised Colombia's policy on crime throughout history (Iturralde 2010).

The DSP was the consolidation of a discourse on security that intensified towards the end of the last century and ignored or downplayed the expansion of paramilitary forces throughout the country. For instance, in 1994, the Colombian government passed Decree 356/94, which approved the creation of private armies for self-defence called CONVIVIR; this was particularly true in Antioquia, the region of which Medellín is the capital. The decree permitted landowners and national companies to effectively have their own security forces.

The decree defined the CONVIVIR groups as "special vigilance and private security services that function in high risk areas to restore tranquillity and ally themselves with military and police agencies" (Decreto 356/94). However, these groups' military purpose was limited by a ruling of the Constitutional Court that stated that they could not supplant the armed forces of the state in their functions nor could they have weaponry that was restricted by law to the armed forces (Sentencia C-572/97). Following this decision, armed CONVIVIR members could only operate through the illegal paramilitary structures, such as the Cacique Nutibara Bloc, the paramilitary unit affiliated with the AUC that would later take control of the Comuna 13. As the

\footnotetext{
${ }^{5}$ Comuna 13 has a total of 19 neighbourhoods.
} 
ruling from the High Court of Medellín declared, the Orión military operation was orchestrated by the military forces with the collusion of the paramilitaries (Auto del Tribunal Superior del Distrito de Medellín, 4 de septiembre de 2013). ${ }^{6}$

The decree 356/94 preceded two declarations of a state of exception in 1995, during the presidential term of Ernesto Samper, the second of which created the so-called Special Public Order Zones. In these zones, the Colombian military was granted broad powers such as powers of seizure without judicial warrant and there were restrictions on the freedom of movement and assembly of the population (Decree 717/96). Regional governments decided which areas merited a declaration of Special Public Order Zones, with two such regions declared near Medellín: Urabá and Chocó. In the case of Comuna 13, the urban district became a "Theatre of Operations" (Iturralde 2009) which, as will be explained later in this article, had important implications for the stigmatisation and criminalisation of Comuna 13's inhabitants.

\subsection{Territorial control in Comuna 13: the competing interests of armed groups}

For the purpose of this article, I have grouped these actors in a time frame that begins in the 1980's and still affects Colombia's present. From the 1980's onwards various actors began arriving in Comuna 13 and competed for its territorial control. These actors are diverse and include now-demobilised guerrilla groups such as M19 ("19 $19^{\text {th }}$ April movement"), drug gangs controlled by the Medellín Cartel and its paramilitary force MAS ("Death to Kidnappers"), militias such as CAP ("Armed Commandos of the People") and the most influential guerrilla organisations of the country: FARC ("Revolutionary Armed Forces of Colombia") and ELN ("National Liberation Army").

\subsection{M19 camps, Medellín Cartel and the paramilitaries}

All of us, or at least the majority of the members of this constituent assembly, are part of what could be called the 'state of siege' generation, I was born during the 'state of siege', and today I live under the state siege. (Navarro Wolff, former M19 Ex-combatant and co-chair/president Constituent assembly 1991. Sesión plenaria de la Asamblea Nacional Constituyente, mayo 20 de 1991, p 82, cited in Barreto 2011)

The beginning of the 1980s marked the arrival of M19 on the periphery of Medellín. M19 was a guerrilla movement that arose in response to the electoral fraud in the presidential elections of 1970. The movement adopted a discourse that sought to promote the implementation of what they understood as "real democracy" in Colombia with the participation of workers and peasants. On various occasions, the movement initiated peace talks with different Colombian governments.

In the mid-1980s, M19 and the Government of Colombia initiated peace negotiations whereby both parties declared a truce and M19 set up peace camps in Comuna 13. These camps consisted of militias, which imposed social order by controlling public transportation, the use of drugs and gangs (Jiménez Ricárdez 1986). However, the peace negotiations ended abruptly when the Colombian military broke the truce by attacking M19 camps, injuring one of the peace negotiators, Antonio Navarro Wolf. After the breach of the truce, M19 decided to continue with their military strategy. They carried out several actions of which the most infamous and bloodiest is the "takeover" of the Palace of J ustice in 1985 in Bogotá (La Toma, 2011).

M19 demobilised in 1990 and played a crucial role in drawing up the Colombian constitution of 1991. As part of the demobilisation, the guerrilla group negotiated an amnesty and became a political party, achieving a rapid rise in popularity in the country. However, in 1990, the same year as their demobilisation, their former leader

6 The paramilitary unit demobilised in December 2003. According to official data, the unit had 868 combatants whose demobilisation is hard to trace. In fact, former AUC commanders in jail have asserted that the demobilisation of this paramilitary Bloc was farcical. For more information on this topic, see Verdad Abierta 2008. 
and presidential candidate Carlos Pizarro was assassinated; demonstrating the dynamics of Colombia's restricted democracy and the limited space for institutionalised political opposition.

The assassination of Carlos Pizarro coincides with the period of extermination of the Patriotic Union, a political party that resulted from the demobilisation of some guerrilla units of FARC and ELN (Gomez Suarez 2007). The political party had important support in rural areas of Antioquia, the department of which Medellin is the capital. However, nearly 5,000 members were exterminated during a decade (Gomez Suarez 2007).

\subsection{War on drugs and counter-insurgency discourses}

Another actor that competed for territorial control in Medellin was the paramilitary group MAS ("Death to Kidnappers").

In a similar fashion to the paramilitaries of the Southern Cone, MAS operated as a death squad linked to Colombia's military forces, adopting a counterinsurgency discourse and setting out to exterminate guerrilla fighters and also leaders of leftist organisations, along with their supporters and relatives (Gomez Suarez 2007). MAS arose from the bowels of the most powerful drug cartel of the 80s: The Medellin Cartel, commanded by mafia baron Pablo Escobar. This shows a pattern of paramilitary violence that has been ignored or downplayed by advocates of laws of exception: the link between the paramilitaries and the drug-trafficking business. This link is very important to understand the role of Cacique Nutibara Bloc in the battle for territorial control of the Comuna.

The combination of the discourses of the War on Drugs and counterinsurgency can be seen in the criminal policy developed by the government of the time, which passed decree 2490/1988. This decree placed guerrilla warfare and drug trafficking on a par. Besides, it established that crimes committed by guerrilla groups such as rebellion would be decided by the same courts that dealt with drug trafficking. For the criminal policy of the 1990s onwards, drug cartels and guerrillas were "the expression of the same public order problem" (Barreto 2011, 61). Paramilitaries were not treated in the same way, thus showing that due to the state of exception the government continued to ignore that paramilitaries were also connected to drug trafficking, because it wanted to use them to achieve its goals.

The most remarkable impact of the War on Drugs discourse in the city of Medellín was the operation of the so-called "Special Search Unit" (Bloque de Búsqueda). This military unit was funded and trained by the US, and it was created to capture the drug baron, Pablo Escobar, after his escape from a Colombian prison. As Lemaitre points out, "identification of enemy collaborators" is central to securitisation processes (Lemaitre 2016), which entails stigmatisation of the community.

Escobar's death in 1993 did not bring an end to violence in the city or drug trafficking. In fact, as Aldo Civico shows, Escobar's enemies allied themselves with the US funded Special Search Unit and after the death of the drug-lord, the so-called "Oficina de Envigado", the enforcement arm of Escobar's Medellin Cartel, gained a monopoly over the drug business. The Oficina was an organisation that controlled enormous amounts of money from the local and international illicit drug markets from the 1990s until very recently. It was run by one of Escobar's enemies, Diego Fernando Murillo, who later became the commander of the Cacique Nutibara Bloc (Civico 2012).

Following Escobar's death, the city was left with urban militias that emerged in the 80's and whose political configuration is difficult to trace. The CAP ("People's Armed Commandos") who operated in the Comuna 13 at the time of the Operation Orión, were initially influenced by Maoist ideas and they imposed their control over many aspects of the population's lives. 


\title{
2.6. A Ciriri's archive
}

On October 23rd, 2015, UNESCO declared Fabiola Lalinde's archive to be documentary heritage of Latin America and the Caribbean. Lalinde's archive documents the struggle against impunity regarding the enforced disappearance (ED) of her son: Luis Fernando Lalinde. The event occurred in 1984 in Verdun, rural Antioquia. The case has a remarkable significance for victims of ED in Colombia because Fabiola Lalinde - now 81 - organised the evidence of the case by herself, showing that her son was executed and subsequently forcibly disappeared by the Colombian army. In so doing, Lalinde posed a counter narrative to the exceptionality politics described above. At first, the army denied the capture of Fernando and asserted that he could have been alias Jacinto, a guerrilla fighter killed in combat. Fabiola faced exile and was sent to prison after denouncing the disappearance of her son.

Fabiola's struggle represents the historical experience of those who have fought against exceptionality in Medellin and Colombia. An important element of her struggle is the solidarity of both local and international communities. Since the military buried Luis Fernando as an NN (nomen nescio), accused him of being a guerrilla fighter, and dismembered his body, it made it very difficult for forensic anthropologists to find his remains. Only three laboratories in the world had the technical capacity to analyse the case. Owing to the solidarity of forensic anthropologist Clyde Snow - "an angel of bone and flesh", in Fabiola's words - a laboratory in Berkeley did the final test that allowed for the identification of Luis Fernando's DNA in 1996 (Lalinde 2018).

In April 2018, Fabiola donated her archive to the National University in Medellín. In her speech she remembered the beginning of her struggle:

\begin{abstract}
When the ruling against Colombia was produced by the ICHR, I was sent to prison under false accusations of being a narco-guerrilla fighter, terrorist and subversive in Antioquia. In the Buen Pastor prison, when unravelling wool with some nuns and other prisoners the image of a Ciriri bird came to my mind, I decided to show who I am and decided to look for Luis Fernando throughout my entire life, even if I didn't find him. I called this operation Ciriri (Lalinde 2018; author's translation). ${ }^{7}$
\end{abstract}

Lalinde's words resonate with those represented in the Yarce $v$ Colombia case described at the outset of the article. These female voices traverse the continuum of violence that renders the lives of victims of ED and displacement invisible. This experience of resistance is very symbolic to the victims of the ED in Comuna 13 which I will address in the final part of the article.

\section{Section II. A gathering against oblivion}

In August 2012, various victims' organisations in Comuna 13 gathered to reflect upon the ways in which the district's violence has been institutionally, academically and socially interpreted. Pensando Comuna 13/Thinking about Comuna 13 was part of a series of community events that took place in the district ten years after the Operation Orión, bringing together many community organisations, NGOs, youth groups, human rights activists, social workers and researchers from local universities in Medellín to reflect upon two harmful events in the district's recent history: the mass displacement of people from El Salado neighbourhood and Operation Orión.

Discussions centred around the meaning and significance of the reports on violence and memory published regionally and nationally as part of a transitional justice discourse by bodies such as the National Centre for Historic Memory, amongst others. Who had recorded the memories of the community, and how those memories were being recorded was discussed. Ultimately, what would the broad memory reports on violence written over the past years mean for the community?

\footnotetext{
${ }^{7}$ A Ciriri bird is a tropical kingbird.
} 
The gathering took place in the Liceo Las Independecias, the local school in El Salado. The location was not fortuitous, as ten years previously, around 170 families (450 people) caught in the midst of crossfire between the Cacique Nutibara Bloc and the CAP camped and stayed in the school for almost a month and a half (CNMH 2011). The paramilitaries displaced 170 of the 200 families who resided in sectors 6 and 7 of El Salado.

During the event, some participants emphasised the importance of remembering the aforementioned incident and clarifying what had happened after the mass displacement that preceded Operation Orión.

Meanwhile, others invited the community to participate in memory projects and resist oblivion by using art to resignify the violent past. A video announcing the creation of an international truth commission was screened before the event closed with the appalling claim that many of the bodies of the forcibly disappeared victims might be buried in a local dumping ground known as La Escombrera, which remains open to this day.

The remaining parts of this article will elaborate on the ways in which the community has coped with these two events (the inter-urban displacement of El Salado and Operation Orión). These two events are fundamental to understand the continuum of violence that has affected the life of the marginalised district. The community's endeavours around memory demonstrate a counter-narrative of resistance to the politics of exception implemented under the Democratic Security Policy. The community's counter-narrative opposes the official discourse of the time, through which military interventions on Comuna 13 were justified on the basis of securitisation. As stated earlier, within the framework of DSP, Comuna 13 became a "theatre of operations", a decision which is representative of the way in which marginalised places and populations are portrayed through the lens of securitisation.

\section{1. "Come out with your little white flags and we will open fire on all of you"}

On May $21^{\text {st }} 2002$ a 12 -hour military operation (Operation Mariscal) took place in Comuna 13 some days prior to the mass displacement from El Salado, with hundreds of members of the Colombian military entering the district in an attempt to combat the guerrilla militias that controlled the area, leaving 35 injured, 15 dead, amongst them nine minors and six soldiers, and 55 people arbitrarily detained (Banco de Datos de Violencia Política del CINEP \& J usticia y Paz 2003).

In the midst of the crossfire, inhabitants of Comuna 13 waved white flags in a call for a ceasefire, and when the operation came to an end, the military stated that the community's reaction had strategically favoured the guerrillas (CNMH 2011, Nieto 2013).

When the Cacique Nutibara Bloc seized sector 6 and 7 of El Salado on J une $29^{\text {th }} 2002$, they cut off the electricity and telephone connections and forced people out of their houses, shouting at them: "Come out with your little white flags and we will open fire on all of you" (CNMH 2011). This was meant to insult the population and deter the social mobilisation that has historically characterised them since the foundation of the neighbourhoods (Nieto 2013). The paramilitary seizure of sectors 6 and 7 resulted in the assassination of Carlos A. Yepes Mazo, a 24 year old civilian, while nine houses were burnt to the ground. On June $30^{\text {th }}$, while the displaced population camped in the local school, inhabitants of other neighbourhoods of the Comuna organised a demonstration in protest against what had happened in sectors 6 and 7. Members of JOLUN ("United Young Leaders"), a local youth group which had gone there for a meeting that morning, decided to stay at the school and assist their displaced neighbours. The youth organisation also joined forces with the neighbourhood's community association, which provided assistance to the displaced population. Eventually, the community's mobilisation caught the attention of the regional Ombudsman, who made a formal complaint about the situation. 


\subsection{El Salado}

Despite El Salado being one of the oldest neighbourhoods in Comuna 13, Sectors 5, 6 and 7 were founded during the 1990s (Atehortúa 2009). The first settlers of sectors 6 and 7 were Afro-Colombians and rural peasants who fled their towns due to the intensification of the war on Colombia's Pacific coast and the northern region of Urabá (CNMH 2011). Upon their arrival in Comuna 13, the displaced population encountered militias of the ELN and the CAP, who eventually coordinated the division and distribution of the peripheral area of El Salado. Both organisations distributed the terrains among the displaced population, providing them with construction materials for their makeshift housing. Once the settlement was formed, other families from nearby neighbourhoods of Comuna 13 who could not afford to pay the rent on their houses moved to these sectors.

Towards the end of the 1990s, the arrival of urban militias of the FARC added yet another feature to the constellations of sovereignty that mediated the everyday lives of Comuna 13's inhabitants (Uribe de Hincapié 1998, INER et al. 2008).

Sectors 5, 6 and 7 are located in the highest part of El Salado. Due to their geographical configuration, these sectors have been technically described as high risk zones, not suitable for human habitation (Atehortúa 2009). By seizing the highest part of the sloping neighbourhood, the paramilitary forces sought to gain territorial control of the entire Comuna 13 and expel the ELN and the CAP. The highest part of this periphery was key to controlling the Comuna given its proximity to rural areas of Antioquia, through which troops and weaponry could be easily transported.

\subsection{Legal interpretations and the continuum of violence}

The situation of the displaced population at Liceo Las Independencias led to the legal recognition of inter-urban displacement in Colombian jurisprudence (Atehortúa 2009). This recognition resulted from a complex interplay amongst different institutions, which provided competing interpretations about the forcibly displaced population at Liceo Las Independencias. The community had to struggle against the institutional indifference promoted by the security discourse of the DSP that labelled all inhabitants of the Comuna 13 as "dangerous". The Uribe government denied the existence of an internal armed conflict and thus situated the problem as one of mere criminal violence that had to be rooted out and thus the actions were justified as what was required to defeat a criminal element in society. ${ }^{8}$ Thus, when the regional Ombudsman requested humanitarian aid for the inhabitants forcibly displaced at Las Independencias school, the request was rejected by Acción Social Antioquia (ASA), the goverment's Social Intervention Agency (Atehortúa 2009). For this bureaucratic body, what happened in El Salado did not fall within the legal definition of forced displacement defined in law 387/97. ASA stressed that events in El Salado should be interpreted as a group of civilians that was detained by an armed group operating in the neighbourhood, specifically CAP militias (CNMH 2011). In the same vein, the institution stated that since the community had remained in the same neighbourhood there was no change in their place of residence, and consequently they could not be described as a displaced population.

ASA reproduced the historical indifference of state institutions when dealing with conflict in Comuna 13. As the Centre for Historic Memory reports, when inhabitants of marginalised neighbourhoods tried to reach state institutions to denounce conflicts occurring in their settlements, the public servants were reluctant to provide assistance (CNMH 2011). They argued that what occurred on the periphery neither concerned city hall nor its institutions, which were supposed to serve inhabitants who resided in the city's legal neighbourhoods (INER et al. 2008). This type of response is representative of the violence embedded in the legalistic understandings that have

${ }^{8}$ For Uribe's justification of the lack of an internal armed conflicto see El Espectador 2011, and for an opposing view during Uribe's term see Semana 2005. 
failed to address the political dimension of displacement in Colombia. As stated previously, in the 1970's the city hall in Medellin did not care about the displaced population that had invaded Moravia, and decided to open the city's dump in what they considered an illegal settlement (Aricapa 2015). Overall, ASA's decision illustrates how violence becomes normalised through institutional practices that foment and codify social indifference (Bourgois 2009).

Following the decision of ASA, the experience of the displaced population in El Salado went through three further interpretive stages: first, the Ombudsman brought the case to Medellin's High Court (Auto del Tribunal Superior del Distrito de Medellín) which ordered ASA to recognise the community camping at Las Independencias school as being in a situation of displacement; second, ASA appealed Medellin's High Court's decision and brought the case to Colombia's Supreme Court, which annulled the sentence declared by Medellin's supreme tribunal; and finally, the Ombudsman brought the case to the Colombian Constitutional Court, which ultimately confirmed the decision of Medellin's tribunal and introduced the concept of inter-urban displacement, setting a judicial precedent (Sentencia T-268/03, Atehortúa 2009). ${ }^{9}$ In spite of the symbolic significance of the ruling of the Constitutional Court we should ask ourselves to what extent a legal category can actually account for the political meaning of displacement in Medellin. Throughout Colombian history displacement has facilitated land dispossession and therefore, understanding the way displacement has worked will reveal practises of the state on its margins. Who has benefitted from the practise of land dispossession and who would benefit if the people from Comuna 13 were "relocated"? Furthermore, what do the lives of the inhabitants of Comuna 13 mean for the Colombian state? These are difficult questions whose answers are not easily provided by the formalistic rationalities of law. In this vein, Norrie's recent work on the role of ethics in socio-legal studies is very significant.

Norrie underscores that the "ethical sense" in the socio-legal approach has been absent since its origination in the $19^{\text {th }}$ century (Norrie 2017). As a result, the ethical analysis of legal thinking has been reductionist and historical structures have not been fully grasped by legal analysis. Therefore, Norrie suggests that a deeper understanding of socio-legal studies should consider the role of ethics in law (Norrie 2017). In analysing cases of mercy killings and genocide, Norrie highlights the importance of notions such as freedom and solidarity to our understanding of ethical behaviour in legal settings. In so doing, he argues that "an understanding of human being and the axiology of freedom and solidarity to which it gives rise can be related to a valid ethical account of good and evil at the core of socio-legal questions" (Norrie 2017, 181).

Although the cases analysed by Norrie belong to a jurisdiction in which exceptionality laws are not implemented in the way they are in Colombia, I find Norrie's call for an ethical understanding of legal forms very relevant to show the juxtaposing relationship between criminal laws of exception, and the narratives of justice upheld by historically marginalised communities in Colombia. Furthermore, Norrie's attempt to re-signify the meaning of the "socio" in the socio-legal approach allows us to explore other sources of enunciation such as the report of the international commission for the clarification of human rights violations in Comuna 13. As Norrie puts it, the ethical dimension is intrinsic to understanding what is at stake in law, even from the point of view of a socio-legal approach (Norrie 2017).

With the above in mind, we should reflect on the impact of legal categories on the construction of subjectivities and narratives about violence. For instance, some

\footnotetext{
9 This action was through an Acción de Tutela, equivalent to a Writ of Amparo in other jurisdictions. Any citizen can petition the courts, under Article 86 of the Colombian Constitution, where fundamental rights are considered to be under threat or at risk. This right of Writ of Amparo is a direct consequence of the negotiations with M-19 and the Constituent Assembly celebrated as part of the accords with this organisation. This right has been severely questioned by right wing sectors of Colombian society, notably those close to Álvaro Uribe.
} 
displaced people reject the legal framework and humanitarian aid provided by the state considering that such a framework is meaningless and will eventually lead to the loss of their territories (Aparicio 2012). Likewise Olarte and Wall (2012) argue, drawing on a case study of displaced populations in Bogotá who invade public spaces, Colombian frameworks of displacement operate as a device of population control, which may lead to the invisibilisation of the political meanings of displacement (Olarte and Wall 2012).

At stake is what Lemaitre terms the grassroots reconstruction in the midst of war and whether the language of the law represent the values and narratives of justice of the communities that have endured multiple forms of violence including at the hands of the state (Lemaitre 2016). It is in the latter that resides the importance of inquiring into the ethical grounds of criminal law of exception (Norrie 2008) and its impact on marginalised communities.

\subsection{Five female leaders against the laws of exception}

The inter-urban displacement in El Salado occurred fifteen years ago. As described in the beginning of this article, the Colombian state was found guilty by the InterAmerican Court of Human Rights of failing to provide adequate security to several human rights defenders who faced displacement, arbitrary detentions and death threats. The findings were issued in 2016 and it is the seventeenth such finding from the body in which the Colombian state has been declared responsible for human rights violations. In fact, Fabio Lalinde's extrajudicial execution was the first case recognised in the Inter-American Commission of Human Rights.

Ana Teresa Yarce, one of the leaders who took the case, was not only arbitrarily detained after Operation Orión, two years later, in 2004, she was assassinated by paramilitaries. Like many inhabitants of Comuna 13, Ana Teresa maintained that the Operation Orión was not just a military operation, but was committed by Colombian state forces working with the paramilitary Cacique Nutibara Bloc. ${ }^{10}$ She was an important representative of a grassroots organisation called AMI Women's association of the Indepenencias (Asociación Mujeres de las Independencias). This association had significant support amongst the population of Comuna 13 who are mainly women and include many widows and single mothers (Nieto 2013). The organisation emerged in the mid-1990s and played an important role in reporting human rights violations committed in Comuna 13, particularly since 2002 (Nieto 2013). Unfortunately, as the scholar Rafael Nieto shows, they became an easy target for both paramilitaries and state forces, which significantly affected the organisation.

Some days after Operation Orión, three of the female leaders were arbitrarily detained for nine days, without judicial warrants. María del Socorro Mosquera, Mery del Socorro Naranjo and Ana Teresa Yarce were eventually released due to the mobilisation of various grassroots organisations and demonstrations held by Ruta Pacífica de las Mujeres ("Women's Peace Path"), a peace movement that brings together different grassroots organisations that campaign for peace throughout the country (Nieto 2013).

The detentions were facilitated by the declaration of a state of "internal unrest" justified by the Democratic Security Policy. Along with the three female leaders, Luz Dary Ospina, AMI's director, was forcibly displaced from the district due to her persistent denunciations of human rights violations linked to Operation Mariscal (Nieto 2013). Myriam Rúa, another female leader of Comuna 13, was also forcibly displaced. She returned to the district after 6 years of exile in Uruguay but nothing remained of the house she and her husband had built. Upon her return she said:

\footnotetext{
10 In 2015, many years after her murder, the Colombian courts in their findings on the Cacique Nutibara Bloc would lend their weight to her belief stating Operation Orión was orchestrated between the Colombian Military and the paramilitary group. See: STS Distrito de Medellín, 24 September 2015.
} 
They only left the land. Our house had two rooms and a huge cellar, kitchen and living room, they totally destroyed it. It was difficult returning to find only ruins. (Durán Núñez 2017)

The female leaders were accused of collaborating with the guerrillas, which clearly shows the stigmatisation caused by the Democratic Security Policy in marginalised neighbourhoods in Colombia. Despite the harmful consequences of such stigmatisation, the narratives of the female leaders in the aftermath of the military operations in Comuna 13 and the assassination of Ana Teresa put forth a counternarrative on the politics of exception that has marked Comuna 13's life. This counternarrative entails historical justice demands, which call for a broader understanding of the continuance of violence after the implementation of criminal laws of exception. As Mery Naranjo commented on the $\mathrm{CIDH}^{\mathrm{D}}$ 's findings, "[i]t leaves me with a bitter taste. Teresa was assassinated. Let's not forget it" (Naranjo, cited in Durán Núñez 2017).

The central element of the counter-narrative put forth by grassroots organisations is that the Comuna 13 did not become a safer place as the government of the time maintained. Rather, it became more dangerous for community leaders, as they were targeted by paramilitary groups and the state. Furthermore, the violence committed by drug organisations, gangs, and armed groups continued, hence the importance of the International Commission for the Clarification of Gross Human Rights Violations (ICCGHRV) that took place in 2012, in which the community denounced the selective killings and enforced disappearances in the neighbourhood. This will be addressed in the remaining part of this article.

\section{Section III. The aftermath of Operation Orión}

Following the aftermath of Operation Orión many inhabitants had to flee Comuna 13 and were forced to settle either in other parts of the city or the country. Some leaders, such as Myriam Rúa, even went into exile, which significantly affected the grassroots processes. After the events in El Salado more cases of inter-urban displacement continued in the city with Comuna 13 accounting for the majority of cases. Despite this setting, many inhabitants refused to flee, including members of youth groups that advanced processes of peaceful resistance through artistic expressions such as graffiti and hip hop (Nieto 2013). One of these important manifestations of resistance is the festival "Revolution without dead people" (Revolución sin muertos). The festival's name illustrates the struggle of the youth who survived the militarisation of Comuna 13 and the posterior paramilitary dominance of the area. The festival has taken place every year since 2004 and it is one of the activities in which the memorialisation processes of the community can be seen. Another initiative that exemplifies the struggle for memory is the graffiti tour during which local guides explain various works of street art representing the violence that has marked the district. One of the most significant features of the tour is the explanation of a mural entitled "Orión never again" (Orión nunca más).

It is interesting to note that despite the difficulties caused by the stigmatisation and the militarisation of Comuna 13, grassroots organisations managed to advance memorialisation processes by themselves. These processes that can be traced to both before and after the military operations, and involve activities such as the ones previously mentioned, caught the attention of the international human rights community. Thus, in October 2012 the International Commission for the Clarification of Gross Human Rights Violations in the urban district was created. This unofficial body was made up of well-known international and national human rights defenders who came to Medellín for three days and listened to the narratives of the victims of Operation Orión and its aftermath. The commissioners visited Comuna 13 and produced a preliminary report which was read out in front of a diverse audience, which brought together grassroots groups, victims' organisations, academics and 
human rights defenders. In the final part of the document, Commissioner Helen Mack addressed the audience with the following statement:

We recognise and commend the organised actions that we have seen (during these three days), especially those of women and young people, who, in addition to their fight against oblivion and denial, embrace life with courage, facing their everyday lives with admirable dignity, always remembering their loved ones. (Informe Preliminar de la Comisión Internacional de Esclarecimiento sobre Graves Violaciones a los Derechos Humanos en la Comuna 13 de Medellín, 2012; author's translation)

\subsection{Solidarity as the possibility of justice}

Mack's words show how an unofficial body is more responsive to the demands for justice from historically marginalised communities in Colombia than the governments that promote exceptionality. In hearing the community's experience of suffering, the commission evokes the spirit of the public opinion tribunals that emerged after periods of atrocity elsewhere in the world, such as the People's Permanent Tribunal, which came to life as a reaction to the impunity surrounding the crimes of the Vietnam War. The commission's response to the demands of justice advanced by the community has a moral force that counters the narratives on securitisation promoted by exceptionality policies, such as the DSP. In responding to the denunciations of the chronic impunity of crimes such as the EDs that occurred in La Escombrera, the commission transcends the legalistic form that has misread historical experience of the community, like in the displacement case of El Salado addressed in section II. In this vein, the commission is an example of solidarity that opposes the moral indifference brought about by the implementation of exceptionality politics, which have systematically stigmatised inhabitants of the Comuna and undermined their voice.

As Norrie's recent work asserts, considering solidarity is important if we are to develop a deeper understanding of the ethical grounds of law. Drawing on Roy Bhashkar's idea of the "eudaimonic condition", Norrie highlights that a deeper understanding of freedom will depend on solidarity. The eudaimonic condition is "a state of universal human flourishing in which the flourishing of each is a condition of the flourishing of all" (Norrie 2017, 177). Although examples of the eudaimonic condition are scarce in history, Norrie reminds us that they have existed as utopian moments. An example of the eudaimonic condition is that of slave leader Toussaint L'Ouverture in Haiti (Norrie 2017). Despite being a free person under French rule in Haiti, T L'Ouverture used the ideals of the French revolution in a radical manner, which compelled him to fight on the site of the slaves. He could not feel fully "free" without the liberation of all the slaves in Haiti and the world. However, the utopian moment was encumbered because L'Ouverture's call for the liberation of all slaves in the world did not have the universal impact he expected. Despite the fact that former slaves in St Domingue and French troops had a common cause against slavery - and even sang La Marseillaise together - the French Democrats did not see such a common ground in that relationship, and thus, decided that their freedom did not extend to slaves in their colonies (Norrie 2017).

It was very symbolic that Commissioner Mack read out the preliminary considerations of the commission. In 2003 she had proven that her sister Myrna Mack was a victim of an extrajudicial execution perpetrated by the Guatemalan forces (Mack $v$ Guatemala, 2003).

Mack's struggle coincides with those of Fabiola Lalinde and Ana Teresa. Yarce. These women's narratives are located in an alternative archive that challenges exceptionality politics and its friend and foe rationality, which undermined the political configuration of Colombia's conflict and did not value the historical experience of marginalised populations. Theirs is a story of resistance whose meaning resides in the struggle for the recognition of their loved ones as victims of exceptionality and 
state repression. They represent what Norrie terms "agentive freedom" (Norrie 2017), which is a fundamental element of our humanity.

\subsection{Unearthing the truth behind the rates}

Another important element of the commission's report draws attention to the occurrence of Enforced Disappearance in the district. This is a very significant point that imbues meaning to the justice demands advanced for more than a decade by the grassroots organisations of the district. The commission bluntly refers to the mass graves located in dumping sites that remain open to this day such as La Escombrera and La Arenera:

The information provided by the authorities indicates that the total number of disappeared persons - prior, during and after Operation Orión - has not been determined. Victims and human rights organisations have documented at least 92 cases. Testimonies by the paramilitaries seem to indicate (the existence of) at least 300 mutilated bodies there. There is an urgent need for a search and locate plan. (Informe preliminar de la Comisión Internacional de Esclarecimiento sobre Graves Violaciones a los Derechos Humanos en la Comuna 13 de Medellín, 2012; author's translation)

In calling for the clarification of the events related to the aftermath of Operation Orión the commission uses sources from victims and human rights organisations, and also testimonies of demobilised paramilitaries. It is a-vital attempt to shed light on the events triggered by the militarisation of Comuna 13. The Commission's preliminary findings question the use of force in the neighbourhood and remind us that the heinous crime of Enforced Disappearance is still a part of Colombia's reality. In so doing, the Commission opposes the official narrative on securitisation that presents DSP as a successful policy, due to the decline of homicide rates in Medellin.

Some months after Operation Orión, the Colombian government initiated peace talks with the AUC who had announced a truce (Rozema 2007). In July 2003, the Ralito agreement was signed between the Colombian state and the AUC (Rozema 2007, Nieto 2013). The agreement gave rise to the Justice and Peace Law 2005, which incorporated the language of transitional justice into Colombian politics. The implementation of the agreement was problematic and extraditions prevented victims from accessing justice.

\subsection{Transitional Justice as an expression of exceptionality}

Through the Ralito agreement, the Colombian government and the AUC entered a Transitional J ustice phase. On the basis of lenient punishment-a maximum of 8 years imprisonment- the right-wing organisation demobilised collectively and agreed to confess their crimes in an unusual procedure call "free version" (Castillejo-Cuéllar 2013). ${ }^{11}$ After three years of free versions, in which the involvement of economic and political actors with the paramilitary forces was revealed, in 2008 the Colombian government had various ex-commanders of the AUC extradited to the US for drugtrafficking (Verdad Abierta 2008).

This resulted in various consequences, of which the most relevant for the purposes of this article is that by extraditing the ex-commanders to the US, the government of the time removed the chance for victims to know the truth of what happened to their relatives. With the ex-commanders in the US it would be very difficult for the victims to learn the truth, mainly because the confessions were originally encouraged by the lenient punishment of the demobilised, entrenched in the Law 975 of 2005;

\footnotetext{
11 The free version is a procedural mechanism established by the law 975 of 2005 . It is a truth delivery mechanism in which demobilised paramilitaries provided information about the paramilitary enterprise. The participation of victims in the free versions was very limited which raised significant criticism from human rights groups. For more on the specifications and difference with legal testimonies, see CastillejoCuéllar 2013.
} 
thus ex-commanders who had been extradited had no motivation to continue the confessions.

Furthermore, the political interests surrounding the implementation of the Peace and Justice Law (Ley 975/2005) gave way to a scenario which Castillejo-Cuéllar (2013) terms "kaleidoscopic truth"; a fragmented truth that favours legalistic understandings of harm that often circumvents the historical experience of victims i.e. the structural injustice caused by long term violence. It is important to note that the law can be seen as an instrumentalisation of the transitional justice discourse historically situated in a globalised post-cold war era - used by the state to legitimate its proxy forces and consolidate the use of violence against just one actor in the conflict - . The idea of securitisation endorsed by DSP has an important part in the instrumentalised use of transitional justice ( $\mathrm{TJ}$ ) with the paramilitaries. Instead of trying them through the transitional justice law for their human rights violations, the state chose to extradite them for drug trafficking crimes.

The implementation of the TJ discourse had a significant impact on the narratives addressed throughout the article. For the government of the time, both the DSP and TJ process with the paramilitaries (Peace and Justice Law 975 of 2005) securitised the marginalised urban setting. However, for survivors and inhabitants of Comuna 13 , the implementation of both DSP and the PJ L did not put an end to the violence and stigmatisation they endured over the past decades. In this vein, two final remarks need to be made: firstly, on the ICHR's ruling addressed at the outset of the article, and secondly, on the International Commission for the Clarification of Human Rights Violations in Comuna 13.

As the 2016 ICHR ruling shows, the Cacique Nutibara Bloc played an important role in Operation Orión. The military and the paramilitary Bloc shared the counterinsurgency discourse of the DSP, and they worked together against a common enemy: the guerrilla groups. In fact, the former commander of the paramilitary group has stated to the Southern District Court of New York, that the control of Comuna 13 "by the police, the army and the paramilitaries had the political aim of eliminating the guerrillas" (Verdad Abierta 2009). The fact that this statement is made in the US illustrates the ways in which the truth became kaleidoscopic (Castillejo-Cuéllar 2013) during the first phase of Transitional Justice in Colombia. When informed of the extradition of the paramilitary commanders, many victims' groups stated: “The truth was extradited" (Impunity, 2010). This prompts the question: what does it mean for the TJ process to prosecute the demobilised fighters for drug-trafficking rather than human rights violations, such as ED, which embody the structural dynamics of Colombia's conflict?

Operation Orión illustrates the entanglement and convergence of the Colombian state with the underworld of organised crime (Civico 2012). Therefore, the relevance of the report produced by the International Commission for the clarification of Human Rights violations in Comuna 13 is that it demonstrates how securitisation discourses make invisible practices such as enforced disappearance or displacement perpetuating the continuum of violence (Bourgois 2009) towards marginalised individuals whose lives seem undervalued through the lens of exceptionality laws. In short, this contrasts with the narratives of denial informed by the security discourse that endorsed the militarisation of Comuna 13.

As aforementioned, the Commission's report is an expression of solidarity with the victims of a crime that traverses Colombian history: Enforced Disappearance. Evoking the words of concentration camp survivor Elie Wiesel, the report states:

What all victims need, above all, is to know that they are not alone; that we haven't forgotten them, that when their voices are drowned out, we should lend them ours, that while their freedom depends on our freedom, the quality of our freedom depends on the quality of their freedom. (Informe Preliminar de la Comisión Internacional de Esclarecimiento sobre Graves Violaciones a los Derechos Humanos en la Comuna 13 de Medellín, 2012) 
In this element of the report the connection between freedom and solidarity highlighted by Norrie becomes apparent again. The report's statement reminds us that although laws of exceptionality try to eradicate the humanity of the populations subjected to them, the demands for justice by survivors and victims bring about expressions of solidarity with common moral grounds. This calls for an ethical analysis of law that requires deeper understanding of freedom (Norrie 2017), one that may allow for what Bhaskar termed the earlier-described eudaimonic condition. In highlighting this ethical element in the socio-legal, the violence of law, represented in its "coordinative character" (Norrie 2017) can be countered. As Norrie puts it, "there is something more in law than unfreedom, even for those who claim that as its essence" (Norrie 2017, 187).

\section{Concluding thoughts}

In this article I have described how exceptionality laws have affected the lives of the inhabitants of a marginalised urban setting in Colombia: Comuna 13. The case study reveals that securitisation discourses are problematic and illustrate an authoritarian nature in modern liberal criminal law (Norrie 2017). In particular, the case study shows the importance of observing the continuum of violence (Bourgois 2009) that traverses the everyday lives of communities subjected to laws of exception. This continuum is situated in the margins of the state (Das and Poole 2004), where the discursive power of the state operates, invisibilising heinous crimes in Colombia, such as enforced disappearance and forced displacement.

The article used an interdisciplinary approach that allowed me to highlight the resistance narratives to the politics of exception in Comuna 13. The significance of the community's narratives is manifested in the fact that they counter exceptionality by providing an alternative record comprised of historical justice demands that urges us to be more cautious in dealing with security discourses. These narratives call for a broader analysis of the structural problems in Colombia, such as the punitive approach to drug policy, the War on Terror and the counterinsurgency criminal law that has led to the stigmatisation of marginalised communities like in the case of Comuna 13.

The narratives upheld by survivors of the 2002 military operations and victims of the EF that took place after the militarisation of Comuna 13 call for an ethical analysis of exceptionality criminal law (Norrie 2017). In this analysis formalistic understandings of law should be in dialogue with the solidarity and resistance efforts of enunciation such as the International Commission for the Clarification of Human Rights violations in Comuna 13 described in the article. At stake is our understanding of how the law values the narratives of historically marginalised communities, whose marginalisation has resulted from political discourses such as exceptionality. In virtue of this, alternative archives such as the one donated by Mrs Fabiola Lalinde to the National University in April 2018 are fundamental. Her Ciriri's Archive shows how historical truth has a moral force that should challenge legalistic understandings of criminality such as exceptionality. Her final remarks at the donation ceremony of her archive to the University are illustrative of the latter:

The archive of a Ciriri bird must remain awkward in an unjust and violent country like ours; rather than a dead object of the past, I leave it as an opportunity for understanding, solidarity and creativity. (Lalinde 2018; author's translation)

\section{References}

Aparicio, J., 2012. Rumores, residuos y estado en la mejor esquina de América: una cartografía de lo humanitario en Colombia. Bogotá: Uniandes.

Aricapa, R., 2015. Comuna 13, crónica de una guerra urbana: de Orión a La Escombrera. Bogotá: Penguin Random House. 
Atehortúa, C., 2009. Caracterización del Desplazamiento Forzado Intraurbano. Opinión Jurídica [online], 18 (16). Available from:

https://revistas.udem.edu.co/index.php/opinion/article/view/87 [Accessed 11 October 2018].

Atiles-Osoria, J., 2018 (in this issue). State of Exception as Economic Policy: A Socio-Legal Analysis of the Puerto Rican Colonial Case. Oñati Socio-legal Series [online], 8 (6), 819-844. Available from: https://doi.org/10.35295/osls.iisl/0000-0000-0000-0975 [Accessed 11 October 2018].

Banco de Datos de Violencia Política del CINEP \& Justicia y Paz, 2003. Comuna 13, la otra versión. Caso Tipo No. 2 [online]. Bogotá: Noche y Niebla. Available from: https://www. nocheyniebla.org/wpcontent/uploads/u1/casotipo/Comuna13.pdf [Accessed 11 October 2018].

Barreto, A., 2011. La Generación del Estado de Sitio: el juicio a la anormalidad institucional en la Asamblea Nacional Constituyente de 1991. Bogotá: Universidad de los Andes, Uniandes.

Benjamin, W., 2007. Critique of Violence. In: W. Benjamin (ed., Peter Demetz), Reflections: Essays, Aphorisms, Autobiographical Writings. New York: Schocken Books, p. 248. (First published in 1978).

Bourgois, P., 2009. Recognizing Invisible violence: A Thirty Year Ethnographic perspective. In: B. Rylko-Bauer, L.M. Whiteford and P. Farmer, eds., Global Health in Times of Violence. Santa Fe, NM: School for Advanced Research Press, pp. 17-40.

Castillejo-Cuéllar, A., 2013. Voces [en la cabeza]: espacialidad, mediaciones teletecnológicas y las verdades caleidoscópicas en el proceso de Justicia y Paz en Colombia. Papeles del CEIC [online], 2013/1 (92). Available from: https://tinyurl.com/yaxh9fx8 [Accessed 11 October 2018].

Centro Nacional de Memoria Histórica, 2011. La Huella invisible de la Guerra Desplazamiento Forzado en la Comuna 13 [online]. Report. Bogotá: CNMH. Available from:

http://www.centrodememoriahistorica.gov.co/descargas/informes2011/inform e_comuna13_la_huella_invisible_de_la_guerra.pdf [Accessed 11 October 2018].

Centro Nacional de Memoria Histórica, 2016. Hasta encontrarlos: el drama de la desaparición forzada en Colombia [online]. Report. Bogotá: CNMH. Available from: http://www.centrodememoriahistorica.gov.co/micrositios/hastaencontrarlos/ [Accessed 11 October 2018].

Civico, A., 2012. "We are illegal, but not illegitimate". Modes of policing in Medellin, Colombia. PoLAR [online], 35 (1), 77-93. Available from: https://doi.org/10.1111/j.1555-2934.2012.01180.x [Accessed 11 October 2018].

Das, V., and Poole, D., 2004. Anthropology in the margins of the State. Santa Fe, NM: School of American Research Press.

Durán Núñez, D., and Martínez Hernández, S., 2017. Corte Interamericana condena al Estado por abusos en la Comuna 13 de Medellín. El Espectador [online], 10 January. Available from: https://www. elespectador.com/noticias/judicial/corte-interamericanacondena-al-estado-abusos-y-excesos-articulo-674055 [Accessed 11 October 2018].

El Espectador, 2011. Uribe da 10 razones para no hablar de conflicto armado. El Espectador [online], 7 May. Available from: 
https://www. elespectador.com/content/uribe-da-10-razones-para-no-hablarde-conflicto-armado [Accessed 11 October 2018].

García Villegas, M., 2008. Un país de estados de excepción. El Espectador [online], 11 October. Available from:

https://www. elespectador.com/impreso/politica/articuloimpreso43317-unpais-de-estados-de-excepcion [Accessed 11 October 2018].

Gomez Suarez, A., 2007. Perpetrator blocs, genocidal mentalities and geographies: the destruction of the Union Patriótica in Colombia and its lessons for genocide studies. J ournal of Genocide Research [online], 9 (4), 637-660. Available from: https://doi.org/10.1080/14623520701644440 [Accessed 11 October 2018].

Impunity, 2010. Documentary. Directed by J.J . Lozano and H. Morris. Switzerland / France / Colombia: Arte / Dolce Vita Films / Intermezzo Films S.A. / Radio Télévision Suisse (RTS) / SRG SSR idée suisse.

INER et al., eds., 2008. Dinámicas de guerra y construcción de paz. Estudio interdisciplinario del conflicto armado en la Comuna 13 de Medellín. Universidad de Antioquia, Instituto de Estudios Regionales (INER) / Universidad de Medellín / Corporación Región / Instituto Popular de Capacitación (IPC).

Iturralde, M., 2009. Castigo, liberalismo autoritario y justicia penal de excepción. Bogotá: Siglo del Hombre / Universidad de los Andes / Pontificia Universidad Javeriana.

Iturralde, M., 2010. Democracies without citizenship: crime and punishment in Latin America. New Criminal Law Review, no 13, pp. 309-332.

Jackson, M., 2002. The Politics of Storytelling: Violence, Transgression, and Intersubjectivity. Copenhagen: Museum Tusculanum Press.

Jiménez Ricárdez, R., 1986. M-19 Paz y guerra en Colombia. Entrevista a Antonio Navarro Wolf. Cuadernos políticos [online], no 45, enero-marzo, 82-104. Available from: http://www.cedema.org/uploads/M-19_1986-03.pdf [Accessed 11 October 2018].

La Toma, 2011 [online]. Documentary. Directed by A. Gibson and M. Salazar. Bogotá: International Center for Transitional J ustice. Available from: https://www.ictj.org/es/multimedia/video/la-toma [Accessed 11 October 2018].

Lalinde, F., 2018. Hagan hablar al archivo, no dejen que guarde silencio [online]. Speech given at the National University of Colombia, 17 April. Available from: https://verdadabierta.com/hagan-hablar-al-archivo-no-dejen-guarde-silenciofabiola-lalinde/ [Accessed 11 October 2018].

Lemaitre, J., 2015. Constitution or barbarism? How to rethink law in "lawless" spaces. In: C. Rodríguez-Garavito, ed., Law and Society in Latin America: A New Map. Abingdon: Routledge, pp. 43-62.

Lemaitre, J., 2016. After the War: Displaced Women, Ordinary Ethics, and Grassroots Reconstruction in Colombia. Social \& Legal Studies [online], 25 (5) 545-565. Available from: https://doi.org/10.1177\%2F0964663916636442 [Accessed 11 October 2018].

Nieto López, J., 2013. Resistencia Civil No Armada. La voz y la fuga de las Comunidades Urbanas. Medellín: Hombre Nuevo / Universidad de Antioquia.

Norrie, A., 2008. Justice on the slaughter-bench: the problem of war guilt in Arendt and J aspers. New Criminal Law Review [online], 11 (2), 187-231. Available from: https://ssrn.com/abstract=1512578 [Accessed 11 October 2018]. 
Norrie, A., 2017. Justice and the Slaughter Bench: Essays on Law's Broken Dialectic. Abingdon: Routledge.

Olarte, C., and Wall, I.R., 2012. The Occupation of Public Space in Bogotá: Internal Displacement and the City. Social \& Legal Studies [online], 21 (3), 321-339. Available from: https://doi.org/10.1177\%2F0964663912442442 [Accessed 11 October 2018].

Oquist, P., 1978. Violencia, Conflicto y Política en Colombia. Bogotá: Instituto de Estudios Colombianos.

Ramírez, M.C., 2010. Maintaining Democracy in Colombia through Political Exclusion, States of Exception, Counterinsurgency and Dirty War. In: E.D. Arias and D.M. Goldstein, eds., Violent Democracies in Latin America. Durham, NC: Duke University Press.

Robinson, J., 2018. Transitional J ustice and the Politics of inscription. Memory, Space and Narrative in Northern I reland. Abingdon: Routledge.

Rozema, R., 2007. Paramilitares y violencia urbana en Medellín, Colombia. Foro Internacional [online], XLVII (3), pp. 535-550. Available from: http: //www. redalyc.org/articulo.oa?id=59911150003 [Accessed 11 October 2018].

Semana, 2005. Sí hay guerra, señor presidente. Semana [online], 2 J une. Available from: https://www.semana.com/portada/articulo/si-guerra-senorpresidente/70763-3 [Accessed 11 October 2018].

Stokes, D., 2003. Why the end of the Cold War doesn't matter: the US war of terror in Colombia. Review of International Studies [online], 29 (4), 569-585. Available from: https://www.jstor.org/stable/20097877 [Accessed 11 October 2018].

Uribe de Hincapié, M., 1998. Las soberanías en vilo en un contexto de guerra y paz. Estudios Políticos [online], no 13, 11-37. Available from: http://aprendeenlinea.udea.edu.co/revistas/index. php/estudiospoliticos/article /view/16280/14112 [Accessed 11 October 2018].

Verdad Abierta, 2008. Bloque Cacique Nutibara [blog post]. Verdad Abierta [online], 15 October. Available from: https://verdadabierta.com/bloquecacique-nutibara- $/$ [Accessed 11 October 2018].

Verdad Abierta, 2009. "Don Berna” implica al ex general Mario Montoya en actividades paramilitares [blog post]. Verdad Abierta [online], 2 March. Available from: https://verdadabierta.com/don-berna-implica-al-ex-generalmario-montoya-en-actividades-paramilitares/ [Accessed 11 October 2018].

Case law

Auto del Tribunal Superior del Distrito de Medellín, Sala de Justicia y Paz, sobre el control de legalidad de cargos de 7 postulados del Bloque Cacique Nutibara. Magistrado ponente: Rubén Darío Pinilla Cogollo. 4 September 2013.

Myrna Mack Chang v Guatemala. Inter-American Court of Human Rights judgment of 25 November 2003 (Merits, Reparations and Costs) [online]. Available from: http://www.corteidh.or.cr/docs/casos/articulos/seriec_101_ing.pdf [Accessed 11 October 2018].

Sentencia C-572/07 de la Corte Constitucional de Colombia. Magistrado Ponente: Jorge Arango Mejía [online]. 7 November 1997. Available from: http://www. corteconstitucional.gov.co/relatoria/1997/C-572-97.htm [Accessed 11 October 2018]. 
Sentencia del Tribunal Superior del Distrito de Medellín, Sala de Justicia y Paz, 24/09/2015. [Sentencia Bloque Cacique Nutibara]. Magistrado ponente: Rubén Darío Pinilla Cogollo [online]. 24 September 2015. Available from: http://docs.elcolombiano.com/SENTENCIA-BLOQUE-CACIQUE-NUTIBARA.pdf [Accessed 11 October 2018].

Sentencia T-268/03 de la Corte Constitucional de Colombia. Magistrado Ponente: Marco Gerardo Monroy Cabra [online]. 27 March 2003. Available from: http://www.corteconstitucional.gov.co/relatoria/2003/t-268-03.htm [Accessed 11 October 2018].

Yarce y otras v Colombia. Corte Interamericana de Derechos Humanos, sentencia de 22 de noviembre de 2016 [online]. Available from: http://www.corteidh.or.cr/docs/casos/articulos/seriec_325_esp.pdf [Accessed 11 October 2018].

\section{Decrees and statutes}

Decreto 0717 de 1996. 18 de abril. Por el cual se dictan unas medidas tendientes a la preservación del orden público. Diario Oficial [online], 42.769, of 19 April 1996. Available from: http://www.secretariasenado.gov.co/senado/basedoc/decreto_0717_1996.ht ml [Accessed 11 October 2018].

Decreto 356 de 1994. 11 de febrero. Por el cual se expide el estatuto de vigilancia y seguridad privada. Diario Oficial [online], 41.220, of 11 February 1994. Available from: https://tinyurl.com/ycls/92u [Accessed 11 October 2018].

Ley 975 de 2005 (julio 25). Ley de justicia y paz por la cual se dictan disposiciones para la reincorporación de miembros de grupos armados organizados al margen de la ley, que contribuyan de manera efectiva a la consecución de la paz nacional y se dictan otras disposiciones para acuerdos humanitarios. Diario oficial [online], 45.980. 25 July. Available from: https://www.cejil.org/sites/default/files/ley_975_de_2005_0.pdf [Con acceso el 5 de octubre de 2018].

\section{Reports}

Informe preliminar de la Comisión Internacional de Esclarecimiento sobre Graves Violaciones a los Derechos Humanos en la Comuna 13 de Medellín, entre los años 2002 y 2003 [online]. Medellín, 16, 17 and 18 October 2012. Available from:

https://cjlibertad.org/index.php?option=com_content\&view=article\&id=639: la s-victimas-tienen-la-palabra\&catid=70: soy-comuna- $13 \& \mid$ temid $=103$ [Accessed 11 October 2018]. 